\section{INVESTMENT RISKS AND THE REGULATOR - EDUCATOR OR SPOILSPORT?}

"Fools, as it has long been said, are indeed separated, soon or eventually, from their money. So, alas, are those who, responding to a general mood of optimism, are captured by a sense of their own financial acumen. Thus it has been for centuries; thus in the long future it will also be."

John Kenneth Galbraith

This seems to be an appropriate time to discuss the financial risks of investing in shares and the legal duty of the financial regulator to raise public awareness of these risks. There are two reasons for this. One is the large rise in share prices in the United Kingdom, and elsewhere, over the last three or so years. The second is the recent death of Professor John Kenneth Galbraith, who did much to try to educate the public about the dangers which exist in the investment world. Galbraith, in such works as The Great Crash 1929 and A Short History of Financial Euphoria, provided excellent insights into the history of financial bubbles and the ways in which they all eventually burst in one way or another.

The role of educating the public by promoting "market awareness" is given statutory footing in section 2 of the Financial Services and Markets Act 2000 which sets out the regulatory objectives of the Financial Services Authority (FSA). One of these objectives is the promotion of market awareness. Section 4 provides that the public awareness objective consists of promoting public understanding of the financial system and this includes, in particular, promoting an awareness of the benefits and risks associated with different kinds of investment or other financial dealing and also the provision of appropriate information and advice.

The current decade has been very interesting from the viewpoint of the equity investor. The decade opened with an international bull market, particularly in technology shares, which at that time was approaching its peak. This bubble burst in spectacular fashion and many private investors suffered extensive loses. There has recently been stockmarket turbulence after a lengthy period of steadily rising prices and a relative lack of volatility.

What has the FSA done to fulfil this regulatory objective and, in relation to stock market investment, is it even realistic to expect that it can make much progress in this area? Why is this? An advert in a newspaper or magazine which shows that an investment product has risen by, for example, 65 per cent in the preceding year will, for many, be far more appealing than the mandatory warning that past performance is not a guide to the future and that prices can go down as well as up. It is after the market has been rising for a considerable time that adverts for all sort of investment products and services start to appear. Tip sheets and investment courses which are marketed using

\section{Articles}

The differing approach to commercial litigation in the European Court of Justice and the courts of

England \& Wales I

2

Co-operative federalism in Australia - an intellectual resource for Europe? I

News

\section{Articles (cont'd)}

The Education Minister and the disqualified teachers

Good stock market governance in the context of

anti-money laundering regimes

phrases such as "secrets of investment success" start to appear. To ensure investor confidence the famous phrase "it's different this time" will be used by many of those involved in selling investments to justify why the market will continue to rise. Experts will be produced to justify why the market will continue to rise and they will often be very convincing. As Galbraith demonstrates, these experts tend to disappear quickly when the market retreats.

Of course, it is always far easier to sell investment products when the market has been rising strongly and this tends to lead to private investors buying at or near the top of the market, and then selling after the market has dropped and money has been lost.

The regulator when pointing out the risks involved in investing in equities may seem like a spoilsport. It is extremely difficult, if not impossible, for any regulator to stop the development of such financial euphoria when markets have been rising so strongly and recent data suggests that, once more, private investors have been piling into the stock market, mostly through investments in OEICS and investment trusts. The FSA has already done much to educate the public about all aspects of financial services, and the risks involved, and for this it is to be praised. It would be too much to expect that anything it publishes will stop some members of the public investing at the wrong time. If such people were to read Galbraith's A Short History of Financial Euphoria they would be less likely to believe that markets only move in an upward direction. The FSA must continue in its duty to raise awareness of the risks but it cannot be expected to stop private investors making investment mistakes.

\section{Andrew Campbell}

Director of the Centre for Business Law and Practice

School of Law

University of Leeds

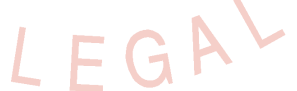

